\title{
CFD Gene
}

National Cancer Institute

\section{Source}

National Cancer Institute. CFD Gene. NCI Thesaurus. Code C84324.

This gene plays a role in complement pathway regulation. 